TRADITIONAL MEDICINE AND PHARMACOLOGY. ACHIEVEMENTS, INNOVATIONS, AND ALTERNATIVES

\title{
2.7 Медична реабілітація хворих на перитоніт
}

Одним із шляхів підвищення ефективності хірургічного лікування захворювань органів черевної порожнини є зменшення частоти ускладнень у найближчому післяопераційному періоді, які знижують ефективність лікування, подовжують терміни стаціонарного лікування. У зв’язку з цим, реабілітаційні заходи, направлені на відновлення порушених вітальних функцій $\epsilon$ проблемою не тільки медичною, а й соціальною [227]. Разом з тим, система реабілітаційних заходів у перші години післяопераційного періоду майже не розпрацьована, недостатньо чітко визначені стратегічні завдання реабілітації, пріоритетні напрямки, методики виконання та оцінки їх ефективності, i, особливо, функційні обов'язки медичного персоналу з їх реалізації [228]. Швидкість і повноцінність відновлення здоров'я хворих залежить від компенсаторної перебудови всіх органів і систем, особливо органів дихання $\mathrm{i}$ кровообігу. Природно, що ця перебудова не може бути досягнута тільки медикаментозною терапією. Доведено позитивний вплив озонотерапії при розповюдженому перитоніті [229]. Використання різних методів та засобів фізичної реабілітації у максимальному ступені сприяє відновленню функцій життєво важливих систем організму, попереджує виникнення післяопераційних ускладнень, сприяє скорішому видужуванню та відновленню працездатності, відновленню їхньої нормальної життєдіяльності залежить від стану органів і систем до операції і від ефективності фізичної терапії [230] Тому індивідуально підібрана методика медичної реабілітації у післяопераційних хворих $\epsilon$ актуальною і своєчасною. В Україні з'являться лікарі фізичної і медичної реабілітації, фізичні та ерготерапевти, які відновлюватимуть функціональні можливості людини. МО3 України вводить нові посади “лікаря фізичної і медичної реабілітації”, “фізичного терапевта”, “ерготерапевта”, “асистента

фізичного терапевта" та "асистента ерготерапевта". Відповідні зміни до наказу від 28 жовтня 2002 року № 385 "Про затвердження переліків закладів охорони здоров'я, лікарських, провізорських посад, посад молодших спеціалістів 3 
TRADITIONAL MEDICINE AND PHARMACOLOGY. ACHIEVEMENTS, INNOVATIONS, AND ALTERNATIVES

фармацевтичною освітою, посад професіоналів у галузі охорони здоров'я та посад фахівців у галузі охорони здоров'я у закладах охорони здоров'я" затверджені МО3 України [231,232]. Однак, функційні обов'язки, завдання та обсяг реабілітаційних заходів, які вони повинні виконувати у ранньому післяопераційному періоді, визначені недостатньо чітко та обгрунтовано. Не окреслено взаємодію цих працівників з лікарями, що курують пацієнта після операції (хірурги, анестезіологи). У 135 пацієнтів, оперованих на порожнистих органах травлення, використано розроблений комплекс реабілітаційних заходів, направлений на профілактику ранніх післяопераційних ускладнень. Контрольну групу склали 23 пацієнти 3 традиційним веденням раннього післяопераційного періоду. За характером хірургічної патології, обсягом оперативного втручання, супутньою патологією групи біли репрезентативні.

Оцінку ефективності проводили шляхом порівняльного аналізу показників функційного стану органів дихання, серцево-судинної системи, кишечнику у динаміці та частоти виникнення ускладнень. Пріоритетним напрямком реабілітаційних заходів були відновлення функційної спроможності вітальних систем (дихальна, серцево-судинна) та шлунково- кишкового тракту. Реабілітаційні заходи включали як медикаментозну корекцію наявних порушень, профілактику прогнозованих ускладнень, так і немедикаментозний вплив на відновлення функційної активності цих органів і систем. При цьому враховували індивідуальні особливості пацієнта з урахуванням наявності та вираженості доопераційних системних змін в цих органах і системах, що можна визначити як персоналізований підхід до реабілітації у ранньому післяопераційному періоді.

Найбільш вразливою у ранньому післяопераційному періоді є дихальна система. Ендотрахеальний наркоз, який сприяє ураженню слизової оболонки трахеї; залишкова дія міорелаксантів; тривале лежаче положення, що утруднює екскурсію грудної клітки; операційна рана черевної стінки, яка виключає на певний час іiі участь у дихальному акті- все це призводить до гіповентиляції 
TRADITIONAL MEDICINE AND PHARMACOLOGY. ACHIEVEMENTS, INNOVATIONS, AND ALTERNATIVES

легень і сприяє розвитку гіпостатичної пневмонії. Однак, методи що використовуються для відновлення порушених функцій дихальної системи у ранньому післяопераційному періоді розроблені схематично, не носять комплексний характер і часто не забезпечують ефективної профілактики післяопераційної пневмонії. Нами використаний комплекс реабілітаційних заходів, направлений на відновлення функції дихальної системи. Реабілітаційний комплекс розпочинали зразу після виходу пацієнта із наркозу. Необхідною умовою його проведення є адекватне знеболення. Для об'єктивної оцінки болю нами запропонований спосіб, що дозволяє кількісно оцінити больові відчуття пацієнтом [233] і проводити їх медикаментозну корекцію шляхом індивідуальної корекції знеболюючих препаратів. Пасивні, а згодом і активні рухи кінцівками за визначеним напрямком, вправи з цілеспрямованим навантаженням певних груп м'язів давали змогу швидко нівелювати залишкову дію міорелаксантів, відновити тонус м'язів не тільки кінцівок, а й всього тулуба. Для відновлення функції дихальної системи нами використаний комплекс реабілітаційних заходів, який включає раннє відновлення тонусу м'язів тулуба і дихальної екскурсії грудної стінки, відновлення прохідності дихальних шляхів та засобів профілактики ателектазу легень. Критерієм ефективності цих заходів була активна поведінка пацієнта у ліжку до кінця першої доби після операції. Так, всі пацієнти дослідної групи впродовж першої доби самостійно змінювали положення тіла у ліжку, повертались на бік, піднімали випрямлені у колінному суглобі нижні кінцівки. Натомість тільки 30,4\% пацієнтів (кожен третій) виконували це самостійно.

Для відновлення прохідності дихальних шляхів використовували поєднання масажу грудної стінки 3 примусовим кашлем за умови передньозаднього стиснення грудної стінки. Доказом ефективності цих засобів $\epsilon$ відходження мокротиння та відсутність сухих хрипів над трахеєю і головними бронхами. Для запобігання гіповентиляції використовували розроблений пристрій, який змушує пацієнта робити видих під тиском через трубку, занурену у ємність з водою. Періодичне п’ятиразове надування з перервою на 
TRADITIONAL MEDICINE AND PHARMACOLOGY. ACHIEVEMENTS, INNOVATIONS, AND ALTERNATIVES

10-15 хвилин давало змогу покращити газообмін, про що свідчило зростання параметрів сатурації, який визначали пульсоксиметром. Персоналізований підхід до проведення цих комплексів полягав у індивідуальному об’ єктивному контролю сатурації кисню i корекції частоти i iнтенсивності вправ для досягнення оптимальних параметрів функції дихальної системи. У 96,3\% пацієнтів дослідної групи до кінця першої доби вдалось досягти сатурації понад 95\%, натомість у контрольній групі цей показник спостерігався за даними листка спостереження тільки у 52,17\% пацієнтів. 3 другої доби післяопераційного періоду хворому рекомендували сидяче положення, яке не перешкоджало довенним інфузіям медикаментозних препаратів і сприяло відновленню функції дихальної системи. 3 третьої доби пацієнти приймали вертикальне положення 3 дозованою ходьбою, нахилами тулуба та присіданнями. У всіх пацієнтів дослідної групи нам вдалось відновити функцію дихальної системи, запобігти ателектазу легень, розвитку післяопераційної пневмонії. Натомість у трьох пацієнтів контрольної групи (13,04\%), яким ці засоби не проводились або виконувались у неповному обсязі, виникли ускладнення збоку органів дихання у вигляді гіпостатичних пневмоній, плевритів, Один із цих пацієнтів помер із -за прогресуючої легенево-серцевої недостатності. Важливе значення у післяопераційному періоді має відновлення функційної активності серцевосудинної системи, особливо після складних операцій та у пацієнтів похилого віку. Основу комплексної реабілітації серцево-судинної системи складає раціональна організація рухового режиму 3 індивідуальним призначенням необхідних засобів фізичної реабілітації. Лікувальна дія фізичних вправ та інших засобів проявляється у вигляді тонізуючого, нормалізуючого, трофічного та компенсаційного впливу. Помірне індивідуально дозоване фізичне навантаження після хірургічних втручань здійснює нормалізуючий вплив на серцево-судинну систему, покращує обмінні процеси в міокарді. Скорочення м'язів під час фізичних вправ сприяє посиленню кровообігу у венозній системі, a розслаблення м'язів полегшує надходження крові 3 капілярів у вени. Поліпшення венозної гемодинаміки під час м'язової роботи позитивно впливає 
TRADITIONAL MEDICINE AND PHARMACOLOGY. ACHIEVEMENTS, INNOVATIONS, AND ALTERNATIVES

на судинний тонус артерій і серця, що посилює кровообіг, усуває порушення периферичного кровообігу, запобігає розвитку венозного застою, тромбоемболій[234, 235].

Нами використаний комплекс фізичних вправ, який підбирався індивідуально і коригувався об'єктивними критеріями функціональної активності серцево-судинної системи - частота пульсу і його динаміка під час виконання вправ за показами пульсоксиметра; величина та динаміка артеріального тиску; за необхідності- моніторування ЕКГ. У перші години після операції дозволяли активні рухи кінцівками з неповним розмахом у повільному темпі. Через 2-3 години після операції пацієнти повертали тулуб у обидва боки. 3 другої доби 4 -5 разів на 10 хв. переводили пацієнта у сидяче положення. При задовільному стані пацієнтів піднімали з ліжка на 2-у добу. Означений комплекс виконувався під наглядом інструктора ЛФК (фізичного терапевта), який коригував інтенсивність та тривалість вправ залежно від параметрів активності серцево-судинної системи. Відновлення порушених функцій кишечнику $\epsilon$ одним з основних завдань реабілітації пацієнтів після абдомінальних операцій. Під час будь-якої лапаротомії кишечник зазнає механічних, бариатричних, хімічних подразнень , які призводять до втрати ним скоротливої здатності, парезу. Стаз кишкового вмісту на тлі порушень секреторних порушень та збереженої всмоктувальної функції призводить до зміни характеру кишкового вмісту, неконтрольованого розмноження мікроорганізмів, утворення токсичних речовин як наслідок дії мікроорганізмів та неповного розщеплення хімусу. Продукти бродіння призводять до збільшення кількості газу у просвіті кишки, наслідком якого $є$ перерозтягнення стінки, iii iшемія, що поглиблює морфофункціональні зміни стінки, втрати нею бар'єрних властивостей. Це сприяє транслокації мікроорганізмів і токсинів із просвіту кишки, розвитку ендотоксикозу. Реабілітація порушених функцій кишечнику починали зразу після операції. Комплекс реабілітаційних заходів включав немедикаментозні та медикаментозні заходи. Для немедикаментозних впливів на відновлення функцій кишечника використовували шлунковий зонд, який зазвичай заводився 
TRADITIONAL MEDICINE AND PHARMACOLOGY. ACHIEVEMENTS, INNOVATIONS, AND ALTERNATIVES

під час операції чи інтубаційний зонд, який під час операції назогастрально проводять через просвіт всієї тонкої кишки. Основне завдання реабілітації зменшити внутрішньопросвітний тиск у порожнистих органах травлення. Досягається це забезпеченням прохідності зонду шляхом періодичного його промивання та активного відсмоктування вмісту шлунку чи кишечнику. Контроль за прохідністю зонду виконується хірургом та лікарем-інтенсивістом, а черговий середній медичний персонал контролює об'єм виділення із зонду, фіксуючи його у листку спостереження. Для пасивного відтоку шлункового та кишкового вмісту ефективними $є$ фізичні вправи - відновлення абдомінального компоненту дихання, яке створює додатковий тиск в черевній порожнині. За адекватного знеболення доцільно активне скорочення м'язів передньої черевної стінки почерговим підніманням випрямленої у колінному суглобі нижньої кінцівки. 3 другої доби пацієнт під контролем інструктора ЛФК (фізичного терапевта) піднімає до верху обидві нижні кінцівки, поступово збільшуючи час утримання їх у такому стані.

3 другої доби за відсутності протипоказів пацієнту рекомендують піднімати верхню половину тулуба, приймаючи сидяче чи напівсидяче положення у ліжку без використання рук, тільки за рахунок скорочення м’язів передньої черевної стінки. Для попередження евентерації пацієнти одягали абдомінальний бандаж, який посилював тонус м'язів черевної стінки та не перешкоджав екскурсії грудної стінки. Критерієм ефективності таких вправ $є$ активний відтік по зонду під час виконання цих вправ. Медикаментозна реабілітація порушених функцій кишечнику полягає у призначенні з другої доби прокінетиків (метапрокламід, церукал), холіноміметиків (церукал), гіперосмолярних розчинів (сорбілакт) та гіпертонічних клізм. Критерієм ефективності такого комплексу є поява перистальтики, відходження газів, а кінцевою метою - самостійні випорожнення кишечнику. Об’ єктивний контроль за ефективністю запропонованих засобів реабілітації можливий за використання розробленого нами способу оцінки скоротливої здатності кишечнику шляхом проведення фоноентерографії 3 кількісною оцінкою параметрів 
TRADITIONAL MEDICINE AND PHARMACOLOGY. ACHIEVEMENTS, INNOVATIONS, AND ALTERNATIVES

перистальтичних хвиль [236]. Метод дає можливість об’ єктивно виявити появу перистальичних шумів, коли аускультативне їх визначення вкрай суб'єктивне, оцінити динаміку складових перистальтики - періодичності появи, інтенсивності скорочення та протяжності, що дозволяє проводити персоналізовану корекцію реабілітаційних заходів по відновленню скоротливої здатності кишечнику. У дослідній групі застосування запропонованого персоналізованого комплексу реабілітаційних заходів нам у всіх пацієнтів вдалось відновити функціональну активність кишечника. Натомість у контрольній групі, де цей комплекс або не застосовувався, або виконувались тільки окремі його компоненти без об’єктивного контролю, у двох пацієнтів (8,70\%) виник стійкий післяопераційний парез кишечнику 3 розвитком динамічної кишкової непрохідності, що потребувало виконання релапаротомій. Це свідчить, що адекватна обгрунтована реабілітація порушених функцій кишечнику у ранньому післяопераційному періоду дає змогу попередити виникнення ускладнень у вигляді динамічної кишкової непрохідності, покращити результати лікування пацієнтів, скоротити терміни їх стаціонарного лікування.

Таким чином, ранне використання реабілітаційних заходів у післяопераційному періоді, які направлені на відновлення функційної активності дихальної, серцево-судинної систем та кишечнику з урахуванням індивідуальних особливостей пацієнта, що виконуються із залученням мультидисциплінарної команди, дозволив запобігти у пацієнтів дослідної групи ускладнень з боку дихальної, серцево-судинної системи та кишечнику, що сприяло швидкому одужанню пацієнтів. Тривалість стаціонарного лікування пацієнтів дослідної групи склало 8, $2 \pm 1,31$ доби, контрольної групи - 12,32 \pm 2,54 діб. Летальних випадків у пацієнтів дослідної групи не було, у контрольній групі помер один пацієнт (4,35\%) від прогресуючої легенево-серцевої недостатності. Отже, розроблений комплекс реабілітації у післяопераційному періоді з персоналізованим підходом та контролем його ефективності дає змогу швидко і ефективно відновити порушену функцію дихальної, серцево-судинної систем, кишечнику запобігти виникненню деяких післяопераційних 
TRADITIONAL MEDICINE AND PHARMACOLOGY. ACHIEVEMENTS, INNOVATIONS, AND ALTERNATIVES

ускладнень, що дозволило покращити результати лікування пацієнтів, скоротити терміни їх стаціонарного лікування. Реалізація реабілітаційних заходів у післяопераційному періоді повинна проводитись мультидисциплінарною командою у складі фізичного терапевта, асистента фізичного терапевта, медичної сестри, проте координатором всіх дій повинен бути лікар фізичної та реабілітаційної медицини. 